\title{
Effect of Protectant Fungicide Application Schedules on Gummy Stem Blight Epidemics and Marketable Yield of Watermelon
}

\author{
Anthony P. Keinath, Department of Plant Pathology and Physiology, Clemson University, Coastal Research and \\ Education Center, Charleston, SC 29414-5332
}

\begin{abstract}
Keinath, A. P. 2000. Effect of protectant fungicide application schedules on gummy stem blight epidemics and marketable yield of watermelon. Plant Dis. 84:254-260.

The watermelon cultivar Royal Star was grown in fall 1996, spring and fall 1997, and spring 1998 and treated with $2.52 \mathrm{~kg}$ a.i./ha of the protectant fungicides mancozeb or chlorothalonil. Spray application schedules used in the experiments included two initiation times, sprays every 7,10 , or 14 days, and two termination times. Severity of gummy stem blight, caused by Didymella bryoniae, was high in fall 1996 and 1997, moderate in spring 1997, and low in spring 1998. In each experiment, fungicide applications reduced the area under the disease progress curve (AUDPC), percent leaf area diseased at the end of the season, time to reach $25 \%$ disease severity, or all three disease measurements relative to the nonsprayed control. In the 1996 and both 1997 experiments, 7-day spray intervals provided more effective disease control than 14day intervals. In general, initiating sprays early reduced gummy stem blight compared with delayed sprays, but spray termination times did not affect AUDPC. In both fall experiments, fungicide applications increased yield of marketable fruit over the no-fungicide control. A 7-day spray interval increased marketable weight compared with a 14-day interval only in fall 1996. Weight of marketable fruit did not differ among treatments in either spring experiment. Differences in disease control among treatments often did not correspond to differences in marketable yields.
\end{abstract}

Additional keywords: Citrullus lanatus

Gummy stem blight, caused by the fungal pathogen Didymella bryoniae (Auersw.) Rehm, is the most prevalent disease on watermelon in the southeastern United States $(9,14,21,26)$ and the Caribbean tropics (4). Over the past 10 years, losses of marketable fruit due to gummy stem blight in nonsprayed experimental plots averaged $43 \%$ of the maximum yields (14). In addition, fruit losses of $17 \%$ to pre- and post-harvest black rot, also caused by $D$. bryoniae, have been reported $(8,15)$. Although crop rotation away from cucurbits for at least 2 years can reduce the incidence and severity of gummy stem blight $(13,25)$, fungicide applications remain the primary control method.

In the United States, fungicides are applied to $70 \%$ of the watermelon acreage and account for $65 \%$ of all pesticides ap-

Corresponding author: A. P. Keinath

E-mail: tknth@clemson.edu

Technical Contribution No. 4517 of the South Carolina Agriculture and Forestry Research System, Clemson University, Clemson, SC. This project was supported with funds from the Southern Region Pesticide Impact Assessment Program and Hatch Project SC01628.

Accepted for publication 20 November 1999.

Publication no. D-2000-0118-04R

(c) 2000 The American Phytopathological Society plied to watermelon (1). Frequent fungicide applications increase production costs and the amount of fungicide active ingredient added to the environment. Following a strict, calendar-based fungicide application schedule is not compatible with integrated pest-management principles. However, previous work has demonstrated that multiple fungicide applications are necessary to increase marketable yields of watermelon $(11,12,22)$. Terminating fungicide applications prematurely or delaying the initial application too long was as ineffective as not spraying when environmental conditions were conducive for rapid progression of gummy stem blight (12). Applying chlorothalonil 1 or 2 weeks before downy mildew symptoms were detected on watermelon did not significantly improve control over applications that began at disease detection (22). Eliminating the last two of eight mancozeb applications did not affect gummy stem blight severity or yield of watermelon (18).

Isolates of $D$. bryoniae resistant to benomyl and thiophanate-methyl were first found in all major watermelon-producing counties of South Carolina in 1995 (16), then in Delaware, Maryland (9), and Texas (20). Therefore, current recommendations emphasize use of protectant fungicides, such as mancozeb and chlorothalonil (6). Because mancozeb has a 5-day preharvest interval, fungicide applications and harvesting must be carefully coordinated.
Although chlorothalonil has a 0-day preharvest interval, the manufacturer cautions against applying it within 21 days of harvest during hot, sunny weather because of a risk of injuring mature fruit. Because of the risk of phytotoxicity, growers are reluctant to use chlorothalonil as the primary fungicide, although chlorothalonil was more effective than mancozeb when conditions were conducive for gummy stem blight development (12).

The primary objective of these experiments was to determine the effect of varying three different components of spray schedules on epidemics of gummy stem blight. Specific treatments were designed to compare different initiation times, application intervals, and termination times in a factorial design. A secondary objective was to compare chlorothalonil and mancozeb, the two protectant fungicides most commonly used on watermelon. The criteria used to evaluate treatments were disease severity and progression and marketable yield of watermelon fruit.

\section{MATERIALS AND METHODS}

General cultural practices. The experiments were conducted at Clemson University's Coastal Research and Education Center (Charleston, SC). The soil was a Yonges loamy fine sand (fine-loamy, mixed, thermic, Typic Albaquults), $\mathrm{pH} 6.1$ to 6.3 , and $1,680 \mathrm{~kg} / \mathrm{ha}$ of dolomitic lime was applied (except in spring 1997, when the $\mathrm{pH}$ was 5.6). The experimental fields had been cropped to crimson clover, white clover, sweet corn and tomato, and pumpkin the year prior to the 1996, spring 1997, fall 1997, and 1998 experiments, respectively. Rye was planted as a winter cover crop in all fields except the field planted to sweet corn and tomato, which was planted with hairy vetch. Rye was mowed and the fields were disced three times; the field planted to vetch was fallow prior to the experiment and was disced twice. Raised beds were shaped $0.9 \mathrm{~m}$ wide on $1.8-\mathrm{m}$ centers and 560 to $900 \mathrm{~kg} / \mathrm{ha}$ of $15 \mathrm{~N}-0 \mathrm{P}$ $12.5 \mathrm{~K}$ fertilizer, based on soil-fertility analyses, was banded in the rows. Ethalfluralin (Curbit 3EC, $1.9 \mathrm{~kg}$ a.i./ha) was sprayed over the fields each year prior to planting; bensulide (Prefar 4-E, $4.5 \mathrm{~kg}$ a.i./ha) also was applied in 1998. Raised beds were injected with 1,3-dichloropropene (Telone II, $32 \mathrm{~kg}$ a.i./ha) prior to the 1996 and both 1997 experiments, but not the 1998 experiment, when plant parasitic 
nematodes were not detected. Raised beds were then covered with white-on-black polyethylene mulch in the fall or black mulch in the spring.

Seedlings of the diploid watermelon cv. Royal Star (two fully expanded true leaves, 12 to 13 days old in the fall and 19 to 21 days old in the spring) were transplanted into every second row and spaced $0.9 \mathrm{~m}$ apart within rows on 5 August 1996, 27 March 1997, 6 August 1997, and 1 April 1998. A side dressing of $224 \mathrm{~kg} / \mathrm{ha}$ of $15 \mathrm{~N}$ 0P-12.5K fertilizer was applied in 1996 and 1997 when fruit began to form; 280 $\mathrm{kg} / \mathrm{ha}$ of $10 \mathrm{~N}-4.4 \mathrm{P}-8.3 \mathrm{~K}$ fertilizer was used in 1998. Cucumber beetles, army worms, whiteflies, and pickle worms were controlled with one or two applications of endosulfan (Thiodan 3EC, 0.84 to $1.0 \mathrm{~kg}$ a.i./ha), one or three applications of esfenvalerate (Asana XL, $0.056 \mathrm{~kg}$ a.i./ha), and zero to two applications of methomyl (Lannate LV, 0.50 to $1.0 \mathrm{~kg}$ a.i./ha) each season. A single application of dicolfol (Kelthane 35, $0.39 \mathrm{~kg}$ a.i./ha) was used in spring 1997 and paraffinic oil (SunSpray oil, 4.7 1/ha) was combined with one endosulfan application in fall 1996. Copper hydroxide (Kocide DF, $0.90 \mathrm{~kg}$ a.i./ha) was applied to all plots as a preventative treatment against watermelon fruit blotch on 20 May 1997 and 14 and 28 May and 9 June 1998. To control powdery mildew, triadimefon (Bayleton 50DF, $0.14 \mathrm{~kg}$ a.i./ha) was applied to all plots on 25 September 1996; 13, 20, and 27 June 1997; and 10 June 1998; thiophante-methyl (Topsin-M, $0.39 \mathrm{~kg}$ a.i./ha) also was applied on 19 June 1998. D. bryoniae is insensitive to triadimefon and over half of the isolates collected from South Carolina were insensitive to thiophanate-methyl (16). Overhead irrigation was applied as needed to supplement rainfall; in 1996 and 1997,5 to $10 \mathrm{~cm}$ were applied in each experiment. In 1998, $24 \mathrm{~cm}$ of irrigation water was applied between 13
May and 26 June to increase leaf wetness periods.

Fungicide treatments. The design for all experiments was a split-plot, randomized complete block with five replications. Plots were single rows $15.2 \mathrm{~m}$ long with $1.8 \mathrm{~m}$ of nonsprayed vines between plots within rows. The two whole-plot treatments were mancozeb or chlorothalonil. The split-plot treatments consisted of 8 to 10 different spray schedules, one of which was a nonsprayed control that was included in both whole plot treatments to balance the experimental design. Mancozeb (Manzate 200DF) and chlorothalonil (Bravo Weather Stik) were both applied at $2.52 \mathrm{~kg}$ a.i./ha with a tractor-mounted hydraulic boom sprayer. Each boom had six hollow cone nozzles (D4 core, \#46 disc, \#25 nylon mesh screen; TeeJet, Chicago) spaced 46 $\mathrm{cm}$ apart, which sprayed fungicide over an area $0.9 \mathrm{~m}$ wide, the width of one singlerow plot. Fungicides were applied in 215 liters/ha of water at $690 \mathrm{kPa}$ in 1996 and spring 1997, 420 liters/ha at $550 \mathrm{kPa}$ in fall 1997, and 470 liters/ha at $690 \mathrm{kPa}$ in spring 1998. At harvest, all fruit were graded for appearance according to United States Department of Agriculture standards (2) and weighed individually. Melons weighing $\geq 6.35 \mathrm{~kg}$ in US \#1 and \#2 grades were considered marketable.

Fall 1996 and spring 1997. A total of 10 split-plot treatments were examined within each whole plot in fall 1996 and spring 1997. Eight of the nine spray schedules were all possible combinations of two initiation times (sprays begun at anthesis [appearance of male flowers] or when gummy stem blight was detected visually anywhere in the field), two spray intervals (every 7 or 14 days), and two termination times (sprays ended just before the first or last harvest; Table 1). Sprays were initiated on 22 August 1996 and 6 May 1997 in the anthesis treatments and on 14 August 1996 and 20 May 1997 in the disease-detection treatments. In the ninth treatment, fungicides were applied according to Melcast, a melon disease forecaster (see below). The tenth treatment within both whole plots was a nonsprayed control. On 21 May 1997, plants between plots in two replications were inoculated with a suspension of $5.5 \times 10^{7}$ conidia $/ \mathrm{ml}$ of $D$. bryoniae. Isolates W195 and W196, both collected from watermelon in Charleston County in fall 1996, were used in equal proportions. Ripe fruit were harvested on 3 and 7 to 9 October 1996, with all remaining fruit harvested on 15 to 16 October and on 23 and 30 June and 7 and 14 July 1997.

Fall 1997. Eight treatments were examined within each whole plot in fall 1997. Six spray schedules were all combinations of two initiation times, anthesis (29 August) or when gummy stem blight was first detected in the field by visual scouting of all plots (5 September), and three spray intervals, 7,10 , or 14 days (Table 2 ). In the seventh treatment, fungicides were applied according to Melcast. All spray applications were terminated on 10 October at first harvest. The eighth treatment was a nonsprayed control within each whole plot. The sticker di-1-p-menthene (Nu-Film-17, Miller Chemical \& Fertilizer Corp., Hanover, PA) was applied with mancozeb at 236 $\mathrm{ml} / \mathrm{ha}$. Ripe fruit were harvested on 14, 21, and 29 October 1997.

Spring 1998. In 1998, 10 treatments were included. The seven spray schedules examined in fall 1997 were repeated, along with two additional treatments of fungicide applications every 7 or 14 days, both initiated when disease was detected on 20 May but terminated on 25 June just before the last harvest. Di-1-p-menthene (Nu-Film17) was added to mancozeb at $59 \mathrm{ml} / \mathrm{ha}$. Ripe fruit were harvested on 17, 24, and 30 June 1998.

Melcast. Beginning 2 weeks after transplanting, daily leaf-wetness duration and air temperatures were recorded with a CR-

Table 1. Area under the disease progress curve (AUDPC) and final disease severity for epidemics of gummy stem blight on watermelon as affected by nine application schedules of chlorothalonil or mancozeb in fall 1996 and spring $1997^{\mathrm{v}}$

\begin{tabular}{|c|c|c|c|c|c|c|c|c|}
\hline \multicolumn{3}{|l|}{ Fungicide schedule } & \multicolumn{3}{|c|}{ Fall 1996} & \multicolumn{3}{|c|}{ Spring 1997} \\
\hline Interval (days) & Initiation & Termination & No. applications & AUDPC & Severity $(\%)^{w}$ & No. applications & AUDPC $^{x}$ & Severity $(\%)^{\mathrm{w}}$ \\
\hline Nonsprayed control & & & 0 & $1,727 \mathrm{a}$ & $99.8 \mathrm{a}$ & 0 & $1,106 \mathrm{a}$ & $70.4 \mathrm{a}$ \\
\hline 7 & Anthesis & First harvest & 7 & $1,297 \mathrm{cde}$ & $97.3 \mathrm{ef}$ & 7 & $558 \mathrm{ef}$ & $62.0 \mathrm{ab}$ \\
\hline 7 & Anthesis & Last harvest & 8 & $1,319 \mathrm{~cd}$ & $97.7 \mathrm{cdef}$ & 10 & $504 \mathrm{f}$ & $53.0 \mathrm{~b}$ \\
\hline 7 & Detection & First harvest & 8 & $1,229 \mathrm{de}$ & $96.5 \mathrm{f}$ & 5 & $629 \mathrm{cdef}$ & $63.8 \mathrm{ab}$ \\
\hline 7 & Detection & Last harvest & 9 & $1,144 \mathrm{e}$ & 97.4 def & 8 & $581 \mathrm{def}$ & $56.0 \mathrm{~b}$ \\
\hline 14 & Anthesis & First harvest & 4 & $1,400 \mathrm{bc}$ & $99.0 \mathrm{abcd}$ & 4 & $743 \mathrm{bcd}$ & $64.0 \mathrm{ab}$ \\
\hline 14 & Anthesis & Last harvest & 4 & $1,492 \mathrm{~b}$ & $99.5 \mathrm{ab}$ & 5 & $678 \mathrm{cde}$ & $60.8 \mathrm{ab}$ \\
\hline 14 & Detection & First harvest & 4 & $1,421 \mathrm{bc}$ & 98.7 bcde & 3 & $878 \mathrm{~b}$ & $70.2 \mathrm{a}$ \\
\hline 14 & Detection & Last harvest & 5 & $1,501 \mathrm{~b}$ & $99.2 \mathrm{abc}$ & 4 & $889 \mathrm{ab}$ & $70.3 \mathrm{a}$ \\
\hline Melcast & $\ldots$ & $\ldots$ & 4 & $1,487 \mathrm{~b}$ & $99.0 \mathrm{abcd}$ & 4 & $800 \mathrm{bc}$ & $68.8 \mathrm{a}$ \\
\hline $\mathrm{MSD}^{\mathrm{y}}$ & $\ldots$ & $\ldots$ & $\ldots$ & 168.0 & $\mathrm{na}^{\mathrm{z}}$ & $\ldots$ & na & 11.4 \\
\hline
\end{tabular}

${ }^{\mathrm{v}}$ Means were calculated across chlorothalonil and mancozeb treatments because there were no fungicide $\times$ treatment interactions. Means within a column with the same letter are not significantly different.

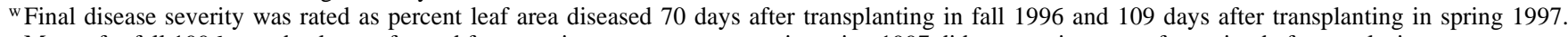
Means for fall 1996 were back-transformed from arcsin-square root; means in spring 1997 did not require a transformation before analysis.

x AUDPC means for spring 1997 were back-transformed from square root; means in fall 1996 did not require a transformation before analysis.

y Minimum significant difference, Waller-Duncan $k$ ratio $t$ test, $k=500(P=0.01)$.

${ }^{\mathrm{z}}$ na $=$ not applicable on back-transformed scale. 
10 micrologger (Campbell Scientific, Logan, UT) and used to calculate Melcast environmental favorability indices (EFI) (19). EFI can range from 0 to 10 each day, with higher values indicating a more favorable environment for disease development (R. X. Latin, personal communication). Fungicides were applied to the Melcast treatment whenever the EFI totaled 35 (17). Environmental monitoring began 2 weeks after transplanting and the first fungicide applications were made on 29 August 1996 and 6 May 1997. In fall 1997 and spring 1998, a cover spray was applied 2 weeks after transplanting and environmental monitoring began immediately thereafter.

Assessment of disease severity. Gummy stem blight severity was assessed visually with a modified Horsfall-Barratt scale (0 to 15). One rating was made per plot after leaves, stems, and vines on all 16 plants in the plot were examined (12). Ratings were done eight times (approximately weekly) between 26 August and 14 October 1996, 15 May and 14 July 1997, 4 September and 24 October 1997, and 5 May and 1 July 1998. Horsfall-Barratt disease ratings were converted to percent leaf area diseased with the midpoint of the percent ranges represented by each rating. Area under the disease progress curve (AUDPC) was calculated from all eight ratings in 1996 and 1997 and the last seven of eight ratings in 1998 (24). Plots of disease progress curves for each replication of each treatment were used to determine empirically the days after planting on which disease severity (percent leaf area diseased) reached 5 and $25 \%$. These disease-severity levels were selected to represent the very early stage (beginning of the logarithmic increase) and a mid-to-late stage of the epidemics in all four experiments.

Statistical analysis. Analysis of variance for a split-plot experimental design was performed with PROC GLM of SAS (version 6.12, SAS Institute, Inc., Cary, NC). Before analysis, data were tested for homogeneity of variance and normality. When there was no fungicide $\times$ treatment interaction, means of the spray schedule treatments were calculated across the two fungicides and fungicide means were calculated across all spray treatments. In addition to the Waller-Ducan $k$ ratio $t$ test to separate all treatment means, preplanned sets of orthogonal, single degree-of-freedom contrasts were used to compare the nonsprayed control with the average of all sprayed plots and to compare the two spray initiation times, spray intervals, and termination times with each other.

\section{RESULTS}

Gummy stem blight was severe in the fall of 1996 and 1997. Epidemics of gummy stem blight progressed rapidly from 40 to 50 days after transplanting until harvest (Figs. 1 and 2). By the final harvest, essentially all foliage was necrotic in the nonsprayed plots. In fall 1997, anthracnose, caused by Colletotrichum orbiculare, contributed to the severe disease and defoliation in nonsprayed plots, but anthracnose did not develop in sprayed plots or in other experiments. In spring 1997, gummy stem blight severity was moderate. Epidemics did not begin to progress rapidly until approximately 80 days after transplanting, reaching a maximum of $70 \%$ leaf area diseased in nonsprayed plots at the last harvest (Fig. 1). In spring 1998, disease severity was low, lower than in spring 1997. Gummy stem blight progressed more slowly than in the other three experiments, reaching only $50 \%$ at the end of the season (Fig. 2).

The lowest number of fungicide applications in any treatment was three sprays made when fungicide was applied every 14 days from disease detection until first harvest in spring and fall 1997 and spring 1998 (Tables 1 and 2). The maximum number of applications made in any season was 10 in spring 1997 for the schedule of anthesis until last harvest, every 7 days (Table 1). In both fall 1997 and spring 1998, Melcast with a cover spray required the same number of sprays as the 7-day treatment which began at disease detection (Table 2).

Application intervals. In fall 1996 and spring 1997, all nine and eight of nine spray schedules, respectively, reduced AUDPC compared with the nonsprayed control (Table 1). In both experiments, the two 7-day-interval treatments begun first (disease detection in 1996 and anthesis in 1997) had significantly lower AUDPC values than all four 14-day intervals (Table 1). In fall 1997, all seven spray schedules again reduced AUDPC compared with the nonsprayed control (Table 2). Both 7-day intervals and Melcast reduced AUDPC compared with the 14-day intervals. In 1998, AUDPC values for the nonsprayed plots were significantly greater than for plots sprayed every 7 or 10 days starting at anthesis until first harvest, with Melcast until first harvest, or every 7 days starting at disease detection through last harvest (Table 2).

In both fall experiments, final disease severity was lower with all spray schedules than in the nonsprayed control (single degree-of-freedom orthogonal constrast, $P=$ 0.0001; Tables 1 and 2). In fall 1996, final disease severity was significantly lower with all four 7-day schedules than with the corresponding 14-day schedules (Table 1). Likewise, in spring 1997, final disease severity was lower for the 7-day treatment sprayed from disease detection to last harvest than for the corresponding 14-day treatment (Table 1). In fall 1997, both 7day intervals and Melcast were more effective than three other fungicide schedules in reducing final disease severity (Table 2). In 1998, eight of the nine spray schedules reduced final disease severity compared

Table 2. Area under the disease progress curve (AUDPC) and final disease severity for epidemics of gummy stem blight on watermelon as affected by seven or nine application schedules of chlorothalonil or mancozeb in fall 1997 and spring 1998, respectively ${ }^{\mathrm{v}}$

\begin{tabular}{|c|c|c|c|c|c|c|c|c|}
\hline \multicolumn{3}{|c|}{ Fungicide schedule } & \multicolumn{3}{|c|}{ Fall 1997} & \multicolumn{3}{|c|}{ Spring 1998} \\
\hline $\begin{array}{l}\text { Interval (days) } \\
\text { (d) }\end{array}$ & Initiation & Termination & No. applications & AUDPC & Severity $(\%)^{\mathrm{w}}$ & No. applications & AUDPC & Severity $(\%)^{\mathrm{w}}$ \\
\hline Nonsprayed control & & & 0 & $2,394 \mathrm{a}$ & $99.5 \mathrm{a}$ & 0 & $164 \mathrm{a}$ & $49.5 \mathrm{a}$ \\
\hline 7 & Anthesis & First harvest & 7 & $1,334 \mathrm{e}$ & $88.0 \mathrm{~d}$ & 8 & $93 \mathrm{~b}$ & $25.9 \mathrm{c}$ \\
\hline 7 & Detection & First harvest & 6 & $1,540 \mathrm{cde}$ & $88.5 \mathrm{~d}$ & 5 & $131 \mathrm{ab}$ & $33.8 \mathrm{bc}$ \\
\hline 10 & Anthesis & First harvest & 5 & $1,559 \mathrm{~cd}$ & $96.5 \mathrm{bc}$ & 6 & $106 \mathrm{~b}$ & $28.7 \mathrm{bc}$ \\
\hline 10 & Detection & First harvest & 4 & $1,771 \mathrm{bc}$ & $92.1 \mathrm{~cd}$ & 4 & $121 \mathrm{ab}$ & $38.1 \mathrm{ab}$ \\
\hline 14 & Anthesis & First harvest & 4 & $1,856 \mathrm{~b}$ & $97.0 \mathrm{~b}$ & 4 & $114 \mathrm{ab}$ & $29.4 \mathrm{bc}$ \\
\hline 14 & Detection & First harvest & 3 & $1,871 \mathrm{~b}$ & $95.8 \mathrm{bc}$ & 3 & $116 \mathrm{ab}$ & $31.6 \mathrm{bc}$ \\
\hline 7 & Detection & Last harvest & $\mathrm{nd}^{\mathrm{x}}$ & nd & nd & 6 & $105 \mathrm{~b}$ & $27.8 \mathrm{bc}$ \\
\hline 14 & Detection & Last harvest & nd & nd & nd & 3 & $124 \mathrm{ab}$ & $32.2 \mathrm{bc}$ \\
\hline Melcast & 2 weeks & First harvest & 6 & $1,364 \mathrm{de}$ & $89.8 \mathrm{~d}$ & 5 & $97 \mathrm{~b}$ & $31.7 \mathrm{bc}$ \\
\hline $\mathrm{MSD}^{\mathrm{y}}$ & $\ldots$ & $\ldots$ & $\ldots$ & 259.2 & $\mathrm{na}^{\mathrm{z}}$ & $\ldots$ & 51.3 & na \\
\hline
\end{tabular}

${ }^{\mathrm{v}}$ Means were calculated across chlorothalonil and mancozeb treatments because there were no fungicide treatment interactions. Means within a column with the same letter are not significantly different.

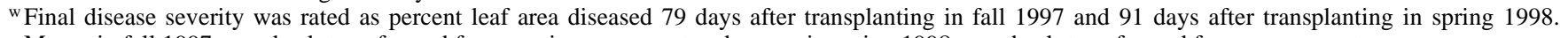
Means in fall 1997 were back-transformed from arcsin-square root and means in spring 1998 were back-transformed from square root.

${ }^{x}$ nd $=$ not done.

${ }^{y}$ Minimum significant difference, Waller-Duncan $k$ ratio $t$ test, $k=500(P=0.01)$.

${ }^{\mathrm{z}} \mathrm{na}=$ not appropriate on back-transformed scale. 
with the nonsprayed control but, at the end of the season, there were few differences among spray schedules (Table 2).

In all four experiments, 5 and $25 \%$ disease severity levels were reached sooner in nonsprayed plots than in sprayed plots (single degree-of-freedom orthogonal contrasts, $P \leq 0.01$; Figs. 1 and 2). Fungicide applications made every 7 days generally delayed $25 \%$ disease severity by 6 to 9 days compared with no fungicide (Table 3). In fall 1996 and 1997 and spring 1997, 14-day schedules generally were more effective at delaying time to reach $25 \%$ disease severity than no fungicide, but were less effective than the corresponding 7-day schedules (Table 3). In addition, fungicide sprays at disease detection and 7day intervals in 1996, anthesis and 7-day intervals in spring 1997, and Melcast and anthesis at 7- or 10-day intervals in fall 1997 also increased days to reach $5 \%$ disease severity compared with not spraying (Table $3)$. In the spring of 1998 , there were no differences among fungicide intervals for time to reach 5 and $25 \%$ disease severity.

Initiation and termination times. Sprays initiated at anthesis were applied 7 to 21 days earlier than sprays initiated at disease detection, except in fall 1996, when disease appeared 9 days after transplanting, well before anthesis at 17 days after transplanting. In fall 1996, AUDPC was lower with 7-day spray schedules initiated at disease detection than at anthesis (single degree-of-freedom orthogonal contrast, $P=0.007$; Table 1). In spring 1997 , fungicide applications begun at anthesis delayed 25\% disease severity (reached 98.2 days after transplanting averaged over intervals, termination times, and fungicides) compared with applications begun at disease detection (96.5 days, $P=0.005$, Table 3). Likewise, the anthesis and 14-day schedule reduced AUDPC compared with 14-day applications begun when disease was detected (Table 1). In fall 1997 with the 10-day frequency, epidemic progress was delayed by initiating sprays at anthesis rather than waiting until disease was detected (Table 3). Melcast increased time to reach $25 \%$ severity and reduced final severity in fall 1997 and spring 1998, when a cover spray was used (Tables 2 and 3), but not in fall 1996 and spring 1997, when a cover spray was omitted (Tables 1 and 3).
Varying termination times between first and last harvest had no effect on AUDPC in any experiment. However, in spring 1997, final disease severity was lower when 7-day sprays continued until last harvest than when sprays stopped at first harvest (single degree-of-freedom orthogonal contrast, $P=0.006$, Table 1).

Fungicides. In fall 1996, AUDPC values (averaged over all spray schedules) were lower with chlorothalonil $(1,298)$ than with mancozeb $(1,506)(F$ test significant at $P=0.01)$. In this experiment, there also was a larger difference between sprayed and nonsprayed treatments with chlorothalonil than with mancozeb (Fig. 1). In both fall experiments, chlorothalonil delayed epidemics compared with mancozeb. In 1996, 25\% disease severity was reached at 48.7 days after transplanting in mancozeb-treated plots (averaged over all spray schedules) and 52.3 days in plots treated with chlorothalonil ( $F$ test significant at $P=0.03$ ); in fall 1997 , the corresponding values were 55.6 and $57.4(P=$ 0.002 ; Figs. 1 and 2). In spring experiments, there were no differences between the two fungicides for AUDPC or days to

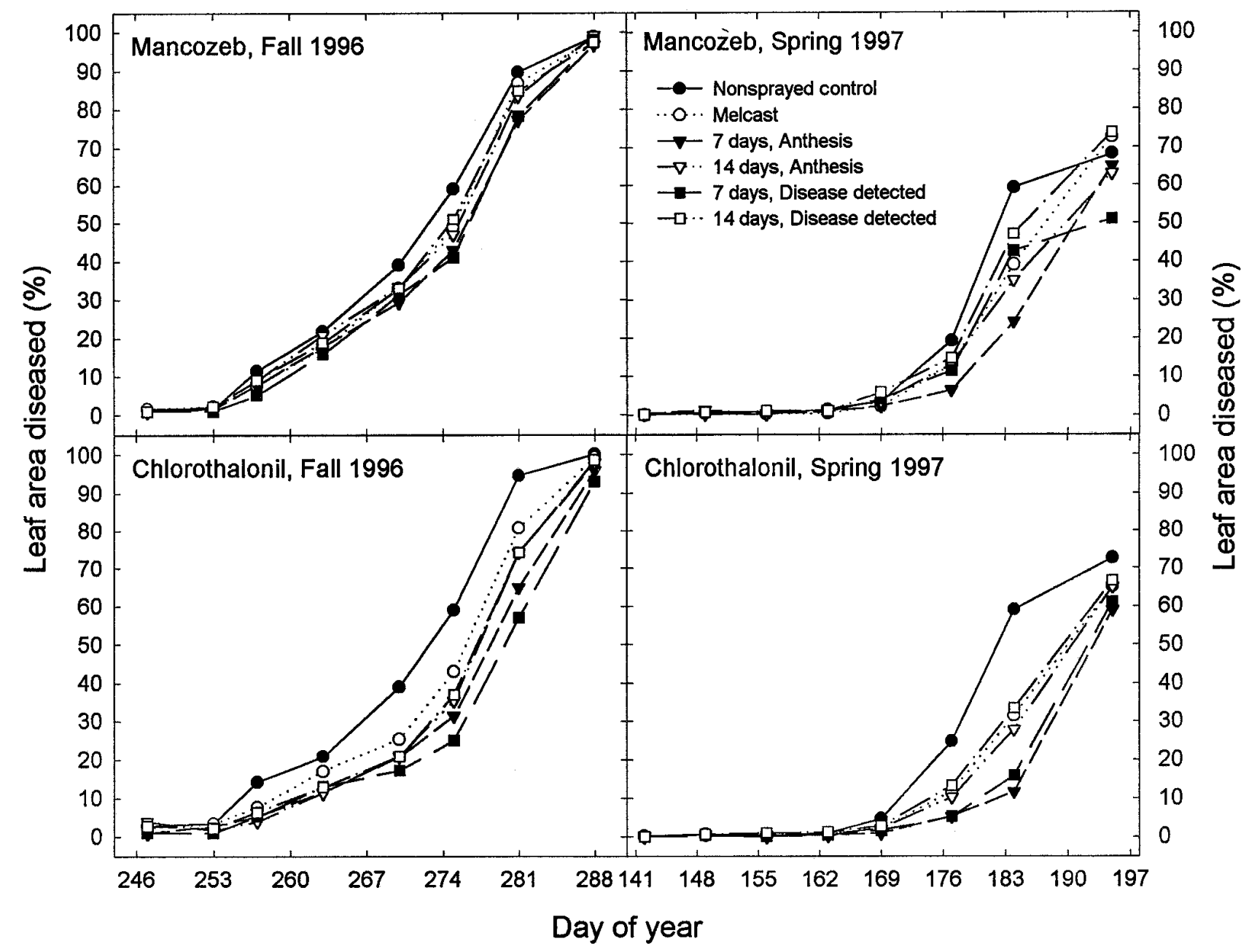

Fig. 1. Gummy stem blight progress curves for watermelon treated with mancozeb or chlorothalonil in fall 1996 and spring 1997. Data points are means of five replications. All fungicide applications were terminated at first harvest. 
reach $25 \%$ disease severity (data not shown). Chlorothalonil increased days to reach 5\% disease severity (87.3) compared with mancozeb (85.1) in spring 1997 (Fig 1).

There were only two fungicide $x$ treatment interactions ( $F$ tests significant at $P \leq$ $0.05)$. In fall 1996, final disease severity was lower with chlorothalonil than with mancozeb for two treatments initiated at disease detection: the 7-day interval which was halted at first harvest and the 14-day interval which continued to last harvest (least-squares means $t$ tests, $P=0.01$; Fig. 1). In fall 1997, AUDPC values for the
Melcast and 7-day/anthesis treatments also were lower with chlorothalonil than with mancozeb $(P=0.01 ;$ Fig. 2$)$. In both cases, treatment means for the other fungicide schedules and the nonsprayed controls did not differ significantly between the two fungicides.

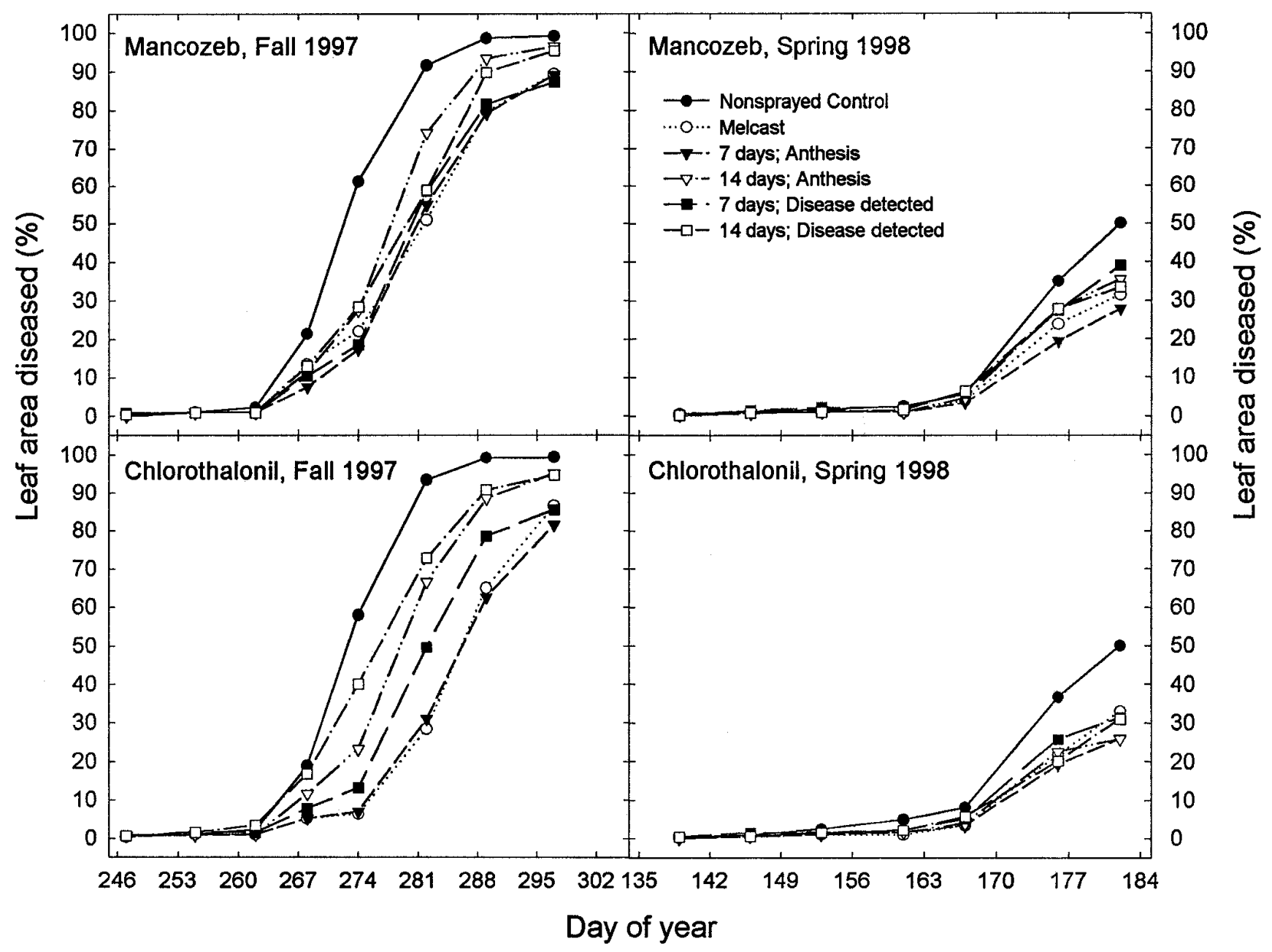

Fig. 2. Gummy stem blight progress curves for watermelon treated with mancozeb or chlorothalonil in fall 1997 and spring 1998. Data points are means of five replications. All fungicide applications were terminated at first harvest.

Table 3. Time to reach 5 and $25 \%$ leaf area affected with gummy stem blight on watermelon treated with chlorothalonil or mancozeb according to different application schedules in four seasons ${ }^{\mathrm{x}}$

\begin{tabular}{|c|c|c|c|c|c|c|c|c|c|c|}
\hline \multicolumn{3}{|l|}{ Fungicide schedule } & \multicolumn{4}{|c|}{ Days after transplanting to $5 \%$ disease severity } & \multicolumn{4}{|c|}{ Days after transplanting to $25 \%$ disease severity } \\
\hline Interval (days) & Initiation & Termination & Fall 1996 & Spring 1997 & Fall 1997 & Spring 1998 & Fall 1996 & Spring 1997 & Fall 1997 & Spring 1998 \\
\hline Nonsprayed control & & & $36.0 \mathrm{~b}$ & $83.4 \mathrm{c}$ & $44.9 \mathrm{c}$ & 73.2 & $46.8 \mathrm{~d}$ & $91.1 \mathrm{f}$ & $50.9 \mathrm{~d}$ & $81.7 \mathrm{~b}$ \\
\hline 7 & Anthesis & First harvest & $39.7 \mathrm{ab}$ & $90.0 \mathrm{a}$ & $50.5 \mathrm{a}$ & 78.4 & $50.7 \mathrm{bc}$ & $99.6 \mathrm{ab}$ & $60.1 \mathrm{a}$ & $88.4 \mathrm{a}$ \\
\hline 7 & Anthesis & Last harvest & $38.5 \mathrm{ab}$ & $89.2 \mathrm{ab}$ & $n d^{y}$ & nd & $51.5 \mathrm{abc}$ & $100.5 \mathrm{a}$ & nd & nd \\
\hline 7 & Detection & First harvest & $39.2 \mathrm{ab}$ & $87.3 \mathrm{abc}$ & $49.4 \mathrm{ab}$ & 75.5 & $52.1 \mathrm{ab}$ & $98.2 \mathrm{abc}$ & $58.4 \mathrm{ab}$ & $85.4 \mathrm{ab}$ \\
\hline 7 & Detection & Last harvest & $41.3 \mathrm{a}$ & $87.1 \mathrm{abc}$ & nd & 76.6 & $54.6 \mathrm{a}$ & $99.0 \mathrm{ab}$ & nd & $87.8 \mathrm{a}$ \\
\hline 10 & Anthesis & First harvest & nd & nd & $50.8 \mathrm{a}$ & 77.1 & nd & nd & $58.1 \mathrm{ab}$ & $87.6 \mathrm{a}$ \\
\hline 10 & Detection & First harvest & nd & nd & $46.7 \mathrm{bc}$ & 77.2 & nd & nd & $54.8 \mathrm{c}$ & $84.8 \mathrm{ab}$ \\
\hline 14 & Anthesis & First harvest & $38.9 \mathrm{ab}$ & $85.2 \mathrm{bc}$ & $46.8 \mathrm{bc}$ & 76.0 & $50.9 \mathrm{abc}$ & $95.7 \mathrm{cde}$ & $55.4 \mathrm{bc}$ & $87.8 \mathrm{a}$ \\
\hline 14 & Anthesis & Last harvest & $37.5 \mathrm{ab}$ & $86.6 \mathrm{abc}$ & nd & nd & $47.9 \mathrm{~cd}$ & $96.9 \mathrm{bcd}$ & nd & nd \\
\hline 14 & Detection & First harvest & $36.8 \mathrm{~b}$ & $84.2 \mathrm{c}$ & $45.9 \mathrm{c}$ & 75.3 & $50.8 \mathrm{bc}$ & 95.0 ed & $54.6 \mathrm{c}$ & $86.1 \mathrm{ab}$ \\
\hline 14 & Detection & Last harvest & $37.0 \mathrm{~b}$ & $83.5 \mathrm{c}$ & nd & 75.7 & $49.5 \mathrm{bcd}$ & $93.8 \mathrm{ef}$ & nd & $85.9 \mathrm{ab}$ \\
\hline Melcast & $\ldots$ & $\ldots$ & $37.7 \mathrm{bc}$ & $85.3 \mathrm{bc}$ & $51.8 \mathrm{a}$ & 77.2 & $50.0 \mathrm{bcd}$ & $95.5 \mathrm{cde}$ & $59.5 \mathrm{a}$ & $86.4 \mathrm{ab}$ \\
\hline $\mathrm{MSD}^{\mathrm{z}}$ & $\ldots$ & $\ldots$ & 4.02 & 4.42 & 3.33 & NS & 3.71 & 2.79 & 3.10 & 5.06 \\
\hline
\end{tabular}

${ }^{\mathrm{x}}$ Means were calculated across chlorothalonil and mancozeb treatments because there were no fungicide treatment interactions. Means within a column with the same letter are not significantly different.

y $\mathrm{Nd}=$ not done.

${ }^{\mathrm{z}}$ Minimum significant difference, Waller-Duncan $k$ ratio $t$ test, $k=500(P=0.01)$. NS $=$ not significantly different. 
Marketable yields. Yields were much greater in spring than in fall crops in both years (Table 4). In general, fungicide applications in fall experiments doubled marketable weight compared with the nonsprayed control (Table 4). Mean marketable yield was significantly greater in plots sprayed every 7 days, $7.1 \mathrm{Mg} / \mathrm{ha}$ (averaged across fungicide and initiation and termination times), than in plots sprayed every 14 days, $3.7 \mathrm{Mg} / \mathrm{ha}$ (single degree-offreedom orthogonal contrast, $P=0.0002$ ). In fall 1997, fungicide applications again increased yield compared with no fungicide. Marketable weight was greater $(P \leq$ $0.05)$ with weekly sprays, Melcast, and the treatment sprayed every 14 days starting at anthesis than in the nonsprayed control (Table 4). In fall 1996, because disease severity was low until after fruit began to mature in spring 1997 and 1998, marketable yield did not differ significantly among treatments. In all four experiments, weights of marketable fruit did not differ significantly between mancozeb and chlorothalonil and there were no interactions between fungicide and treatment. Spray initiation and termination times also did not affect marketable yields.

\section{DISCUSSION}

In both seasons, fungicide applications clearly reduced gummy stem blight severity compared with the no-fungicide control in these experiments. Fungicides were effective for disease control regardless of the overall level of gummy stem blight and regardless of when disease severity began to increase during the season. However, fungicides significantly increased marketable yield of watermelon only in the fall, when gummy stem blight was severe.

Application interval was the most important component of the fungicide schedules examined in these experiments. It was more important than initiation time, termination time, or fungicide active ingredient for improving disease control and increasing weight of marketable fruit. In three of four experiments, 7-day intervals were more effective overall than 14-day intervals, although 14-day spray intervals reduced AUDPC, final disease severity, time to reach $25 \%$ disease severity, or all three measurements relative to the nonsprayed control in all experiments. The 14-day intervals, however, did not increase marketable yields over the nonsprayed control, except for one treatment in fall 1997.

Earlier fungicide sprays always resulted in less disease. Normally, anthesis occurred before disease was detected, except in fall 1996. Furthermore, Melcast performed similarly to the 7-day spray intervals when an initial fungicide application was made 2 weeks after transplanting, but Melcast was not different from 14-day intervals without this cover spray. Berger (5) suggested that fungicide applications early in the season were more effective because the amount of inoculum is lower than later in the season. In a previous study, delaying chlorothalonil applications until vines covered the rows did not reduce gummy stem blight compared with the nonsprayed control (11). In that study, delayed applications with both 7- and 14-day frequencies were less effective than early applications. Epidemics of downy mildew progressed more slowly on watermelon sprayed with chlorothalonil before symptoms appeared than on plants sprayed after symptoms appeared (22).

Differences between initiation times often were influenced by the application interval. With frequent (7-day) or infrequent (14-day) sprays, initiation time was less important than the interval, but with intermediate (10-day) intervals, initiation time could influence the course of the epidemic. No differences were detected be- tween treatments in which fungicide applications were terminated at first or last harvest in fall 1996 and spring 1998, probably because termination times only differed by 7 to 9 days between first and last harvests in these experiments. Differences were observed in spring 1997, when fungicide applications continued an additional 21 days after first harvest, resulting in three additional applications with the 7day schedule and one additional application with the 14-day schedule.

When there was a difference between the two protectant fungicides used in these experiments, chlorothalonil always provided better disease control than mancozeb, although both fungicides were applied at the same rate. This difference has been observed previously with gummy stem blight on watermelon (12), Alternaria leaf blight of muskmelon (27), and black Sigatoka of banana (29). In one study, retention of chlorothalonil was better than that of mancozeb on foliage under simulated rain events (27). In another study, germination of Mycosphaerella fijiensis ascospores was inhibited by lower effective concentrations of chlorothalonil than mancozeb (29). D. bryoniae ascospores are known to serve as inoculum for secondary cycles of gummy stem blight on watermelon in the southeastern United States. (23). Didymella spp. are closely related to Mycosphaerella spp. (7); therefore, $D$. bryoniae also may be more sensitive to chlorothalonil than mancozeb.

Season of the year clearly impacted the effectiveness of fungicide applications to control gummy stem blight. Disease progression, most noticeably onset of symptoms, was delayed in the spring compared with the fall. This altered the effectiveness of the fungicide schedules. For example, in spring 1997, delaying initiation until disease was detected but continuing applica-

Table 4. Weight of marketable watermelon fruit as affected by different application schedules of chlorothalonil or mancozeb for gummy stem blight control $^{u}$

\begin{tabular}{|c|c|c|c|c|c|c|}
\hline \multicolumn{3}{|l|}{ Fungicide schedule } & \multicolumn{4}{|c|}{ Weight of marketable fruit $(\mathrm{Mg} / \mathrm{ha})^{\mathrm{v}}$} \\
\hline Interval (days) & Initiation & Termination & Fall $1996^{w}$ & Spring 1997 & Fall $1997^{\mathrm{x}}$ & Spring 1998 \\
\hline Nonsprayed control & & & $2.8 \mathrm{~b}$ & 36.9 & $8.4 \mathrm{c}$ & 59.1 \\
\hline 7 & Anthesis & First harvest & $9.1 \mathrm{a}$ & 35.1 & $15.7 \mathrm{a}$ & 57.0 \\
\hline 7 & Anthesis & Last harvest & $6.1 \mathrm{ab}$ & 33.8 & $\mathrm{nd}^{\mathrm{y}}$ & nd \\
\hline 7 & Detection & First harvest & $6.9 \mathrm{ab}$ & 31.3 & $15.4 \mathrm{ab}$ & 63.1 \\
\hline 7 & Detection & Last harvest & $6.5 \mathrm{ab}$ & 41.6 & nd & 67.2 \\
\hline 10 & Anthesis & First harvest & nd & nd & $11.7 \mathrm{abc}$ & 67.9 \\
\hline 10 & Detection & First harvest & nd & nd & $9.5 \mathrm{bc}$ & 64.2 \\
\hline 14 & Anthesis & First harvest & $3.5 \mathrm{ab}$ & 33.0 & $16.7 \mathrm{a}$ & 66.6 \\
\hline 14 & Anthesis & Last harvest & $4.1 \mathrm{ab}$ & 32.1 & nd & nd \\
\hline 14 & Detection & First harvest & $4.5 \mathrm{ab}$ & 30.9 & $14.3 \mathrm{abc}$ & 70.5 \\
\hline 14 & Detection & Last harvest & $2.4 \mathrm{~b}$ & 40.0 & nd & 71.5 \\
\hline Melcast & $\ldots$ & $\ldots$ & $4.4 \mathrm{ab}$ & 32.4 & $15.1 \mathrm{ab}$ & 68.5 \\
\hline $\mathrm{MSD}^{\mathrm{z}}$ & $\ldots$ & $\ldots$ & na & NS & 19.5 & NS \\
\hline
\end{tabular}

" Means were calculated across mancozeb and chlorothalonil treatments, because there were no fungicide treatment interactions.

${ }^{\vee}$ Means for fall 1996 are back-transformed means from square root $(x+0.5)$ transformation; means in the other three experiments did not require a transformation before analysis.

${ }^{\text {w}}$ Means within a column with the same letter are not significantly different, Waller-Duncan $k$ ratio $t$ test, $k=500$ (approximates $P=0.01$ ).

${ }^{\mathrm{x}}$ Means within a column with the same letter are not significantly different, Waller-Duncan $k$ ratio $t$ test, $k=100$ (approximates $P=0.05$ ).

$\mathrm{y}$ nd $=$ not done in this season.

${ }^{\mathrm{z}}$ Minimum significant difference; na $=$ not appropriate on back-transformed scale. NS $=$ not significantly different at $P \leq 0.05$. 
tions until the last harvest was the most effective schedule. In spring 1998, when gummy stem blight severity increased slowly, all fungicide intervals were equally effective in delaying time to reach 5 and $25 \%$ severity. With slower or delayed disease progression, a less-effective fungicide (e.g., mancozeb) could be used, the spray interval could be decreased (e.g., to 14 days), or the initiation time could be delayed (e.g., until disease detection).

Marketable yields were much greater in spring crops than in fall crops. Temperatures are more favorable in the spring than in the fall for a warm-season crop like watermelon, when plants mature with increasing temperatures rather than decreasing temperatures. Gummy stem blight epidemics also began sooner, progressed more rapidly, and reached a higher final level in the fall than in the spring. Differences among treatments in disease control often did not correspond to the differences observed in marketable yields. In Indiana, applying chlorothalonil every 7 days reduced AUDPC compared with a 14-day spray interval, but yields did not differ between these two treatments (17). In another study, watermelon yields were not increased by 7- or 14-day applications of chlorothalonil, although these treatments reduced gummy stem blight compared with the nonsprayed control (10). Apparently, watermelon plants can compensate for loss of some healthy leaf area to gummy stem blight to the extent that marketable yields are not always significantly affected. Conversely, protectant fungicides may not be effective enough against gummy stem blight to significantly increase yields under disease-conducive conditions. On melon (Cucumis melo), the systemic fungicide tebuconazole was more effective than mancozeb or chlorothalonil at reducing incidence and severity of gummy stem blight (28).

In the fall or under environmental conditions conducive for gummy stem blight (i.e., prolonged periods of leaf wetness at moderate temperatures; 3 ), chlorothalonil is the recommended protectant fungicide. Applications should begin at anthesis, or sooner if symptoms appear, and continue weekly or according to Melcast EFI thresholds of 35 or less (17). In the spring or in seasons with infrequent precipitation or short dew periods, either mancozeb or chlorothalonil can be effective. Applications could start at anthesis and continue every 7 or 14 days or according to Melcast with a 35-EFI threshold. Alternatively, with a 7-day interval, the first application may be delayed until disease appears, provided that fields are scouted at least weekly so that initial symptoms are not overlooked.

\section{ACKNOWLEDGMENTS}

I thank W. May III, V. DuBose, and K. Moore for technical assistance; and R. X. Latin for use of the Melcast disease forecaster.

\section{LITERATURE CITED}

1. Allred, A. J., and Lucier, G. 1990. The U.S. watermelon industry. U. S. Dep. Agric. ERS, Staff Rep. No. AGES-9015.

2. Anonymous. 1978. United States Standards for Grades of Watermelons. U. S. Dep. Agric. Agric. Marketing Serv. Fed. Reg. Doc. 7735631.

3. Arny, C. J., and Rowe, R. C. 1991. Effects of temperature and duration of surface wetness on spore production and infection of cucumbers by Didymella bryoniae. Phytopathology 81:206-209.

4. Bala, G., and Hosein, F. 1986. Studies on gummy stem blight disease of cucurbits in Trinidad. Trop. Agric. (Trinidad) 63:195-197.

5. Berger, R. D. 1977. Application of epidemiological principles to achieve plant disease control. Annu. Rev. Phytopathol. 15:165-183.

6. Cook, W. P., Keinath, A. P., and Griffin, R. P. 1995. Growing watermelons in South Carolina. Clemson Univ. Ext. Bull. 121.

7. Corlett, M. 1981. A taxonomic survey of some species of Didymella and Didymellalike species. Can. J. Bot. 59:2116-2042.

8. Dow, A. T., Segall, R. H., Hopkins, D. L., and Elmstrom, G. W. 1978. Effects of storage temperature and field fungicide treatments on decay of Florida watermelons. Proc. Fla. State Hortic. Soc. 91:149-150.

9. Everts, K. L. 1999. First report of benomyl resistance in Didymella bryoniae in Delaware and Maryland. Plant Dis. 83:304.

10. Johnson, C. E., and Payne, J. T. 1994. Evaluation of fungicides for gummy stem blight control on watermelon. Fungic. Nematic. Tests 49:177.

11. Johnson, C. E., Payne, J. T., and Buckley, J. B. 1995. Evaluation of fungicides for gummy stem blight control on watermelon. Fungic. Nematic. Tests 50:184.

12. Keinath, A. P. 1995. Fungicide timing for optimum management of gummy stem blight epidemics on watermelon. Plant Dis. 79:354358.

13. Keinath, A. P., DuBose, V. B., May, W. H., III, and Latin, R. X. 1998. Comparison of seven fungicide intervals to control gummy stem blight in a fall watermelon crop. Fungic.
Nematic. Tests 53:268.

14. Keinath, A. P., and Duthie, J. A. 1998. Yield and quality reductions in watermelon due to anthracnose, gummy stem blight, and black rot. Pages 77-90 in: Recent Research Developments in Plant Pathology, Vol. 2. Research Signpost, Trivandrum, India.

15. Keinath, A. P., May, W. H., III, and DuBose, V. B. 1997. Comparison of eight fungicide intervals to control gummy stem blight on watermelon. Fungic. Nematic. Tests 52:195.

16. Keinath, A. P., and Zitter, T. A. 1998. Resistance to benomyl and thiophanate-methyl in Didymella bryoniae from South Carolina and New York. Plant Dis. 81:479-484.

17. Latin, R. 1997. Evaluation of fungicides for control of gummy stem blight of watermelon. Fungic. Nematic. Tests 52:196.

18. Latin, R. X. 1987. Effect of kind and number of fungicide applications on gummy stem blight of watermelon. Fungic. Nematic. Tests 43:163.

19. Latin, R., and Evans, K. J. 1996. Development and delivery of a forecaster for Alternaria leaf blight of muskmelon. (Abstr.) Phytopathology 86:S106.

20. Miller, M. E., Isakeit, T., and Hernandez, R. A. 1998. Evaluation of fungicides for gummy stem blight control on muskmelon. Fungic. Nematic. Tests 53:159.

21. Schenck, N. C. 1960. Watermelon disease incidence in central Florida. Plant Dis. Rep. 44:556-568.

22. Schenck, N. C. 1968. Fungicidal control of watermelon downy mildew and its relationship to first infection in the field. Plant Dis Rep. 52:979-981.

23. Schenck, N. C. 1968. Epidemiology of gummy stem blight (Mycosphaerella citrullina) on watermelon: ascospore incidence and disease development. Phytopathology 58:1420-1422.

24. Shaner, G., and Finney, R. E. 1977. The effect of nitrogen fertilization on the expression of slow-mildewing resistance in Knox wheat. Phytopathology 67:1051-1056.

25. Sitterly, W. R. 1969. Effect of crop rotation on cucumber gummy stem blight. Plant Dis. Rep. 53:417-419.

26. Sitterly, W. R., and Keinath, A. P. 1996. Gummy stem blight. Pages 27-28 in: Compendium of Cucurbit Diseases, T. A. Zitter, D. L. Hopkins, and C. E. Thomas, eds. APS Press, St. Paul.

27. Suheri, H., and Latin, R. X. 1991. Retention of fungicides for control of Alternaria leaf blight of muskmelon under greenhouse conditions. Plant Dis. 75:1013-1015.

28. Vawdrey, L. L. 1994. Evaluation of fungicides and cultivars for control of gummy stem blight of rockmelon caused by Didymella bryoniae. Aust. J. Exp. Agric. 34:1191-1195.

29. Washington, J. R., Cruz, J., and Fajardo, M. 1998. Detection of chlorothalonil in dew water following aerial spray application and its role in the control of black Sigatoka in banana. Plant Dis. 82:1191-1198. 